\title{
Preliminary studies of cell culture strategies for bioprocess development based on HEK293 cells
}

\author{
Leticia Liste-Calleja*, Jonatan López-Repullo, Martí Lecina, Jordi Joan Cairó \\ From 23rd European Society for Animal Cell Technology (ESACT) Meeting: Better Cells for Better Health \\ Lille, France. 23-26 June 2013
}

\begin{abstract}
Background
The use of human embryonic kidney cells (HEK293) for recombinant protein or virus production has gained relevance along the last years. They are specially recommended for transient gene expression and adenovirus or adeno-associated virus generation [1,2]. To achieve high volumetric productivities towards bioprocess optimization, the concentration of biocatalizer (i.e. animal cells) must be enhanced. The limits for cell growth are mainly related to the accumulation of metabolic by-products, or the depletion of nutrients [3]; therefore, cell cultures strategies must be developed. In this work, we have explored Punctual Feeding and Media Replacement cell culture strategies to over perform the limit on $\mathrm{Xv}_{\max }$ encountered on batch culture mode. Finally, we scaled up cell culture in order to control other parameters (i.e. $\mathrm{pO}_{2}$ ) that could be limiting cell growth.
\end{abstract}

\section{Materials and methods}

The cell line used in this study was HEK293SF-3F6 (kindly provided by Dr. A.Kamen, NRC-BRI). The basal medium for all cell cultures was SFMTransFx-293 (Hyclone, Thermo Scientific) supplemented with 5\% (v/v) of FBS and $4 \mathrm{mM}$ GlutaMAX (Gibco, Invitrogen). For Punctual Feeding and FedBatch Fementation Cell Boost 5 (Hyclone, Thermo Scientific) was used. Batch, media replacement and punctual feeding experiments were performed in 125-ml plastic shake flasks (Corning Inc.) shaken at $110 \mathrm{rpm}$ in an orbital shaker at $37^{\circ} \mathrm{C}$, 95\% humidity, $5 \% \mathrm{CO}_{2}$ incubator. FedBatch Fermentation was carried out in Bioreactor Braun-MCD (2 L) with mechanical agitation at $80 \mathrm{rpm}, \mathrm{pH}$ set point 7.1 and $\mathrm{pO}_{2}$ set point $50 \%$. Viable cell density and viability were determined by trypan blue exclusion method and

\footnotetext{
* Correspondence: Leticia.Liste@uab.cat

Chemical Engineering Department, Universitat Autònoma de Barcelona,
} Cerdanyola del Vallès, 08193, Spain

\section{Results}

Characterization of HEK293 cell culture in batch operation was initially performed. It was encountered that cell growth was extended for $168 \mathrm{~h}$ reaching approximately $7 \cdot 10^{6} \mathrm{cell} / \mathrm{mL}$ of cell density (Figure 1.1 ). Nevertheless, maximal cell growth rate $\left(\mu_{\max }\right)$ was only maintained for $96 \mathrm{~h}$. As glucose and lactate were not at limiting concentrations [4], nutrient limitation different from glucose arose as the first hypothesis for this decrease on cell growth rate. Therefore, punctual additions of nutritional supplement for HEK293 were carried out. $\mathrm{Xv}_{\max }$ was significantly increased in comparison to basal media, reaching cell densities as high as $17 \cdot 10^{6} \mathrm{cell} / \mathrm{mL}$ (Figure 1.2). Nevertheless, we could not overcome this limit on $\mathrm{Xv}_{\max }$ regardless the number of punctual feedings performed. Moreover, nutrient addition did not elongate $\mu_{\max }$ period $\left(t_{\mu}\right)$. These results suggested that by-product accumulation different from lactate could be limiting cell growth. In order to validate the hypothesis, complete media replacement (up to three replacements) was studied (Figure 1.3). Although this strategy enabled to extend $t_{\mu}$ up to $168 \mathrm{~h}$ of cell culture, the maximal cell density reached was similar to nutrient addition strategy (1MR: $12 \cdot 10^{6} \mathrm{cell} / \mathrm{mL}$; $2 \mathrm{MR}: 16 \cdot 10^{6} \mathrm{cell} / \mathrm{mL}$; $3 \mathrm{MR}: 18 \cdot 10^{6} \mathrm{cell} /$ $\mathrm{mL}$ ). This limit on $\mathrm{Xv}_{\max }$ encountered on shake flask might be related to a limitation on $\mathrm{pO}_{2}$. Thus, the cell culture system was changed towards a bioreactor with controlled $\mathrm{pO}_{2}$ (maintained between $20-60 \%$ of air saturation). In addition, a continuous feeding using a pre-fixed profile addition was implemented. As it can be noticed in Figure 1.4, FedBatch operation in bioreactor enabled to beat the limit encountered in shake flask system, reaching cell densities of $27 \cdot 10^{6}$ cell $/ \mathrm{mL}$. 


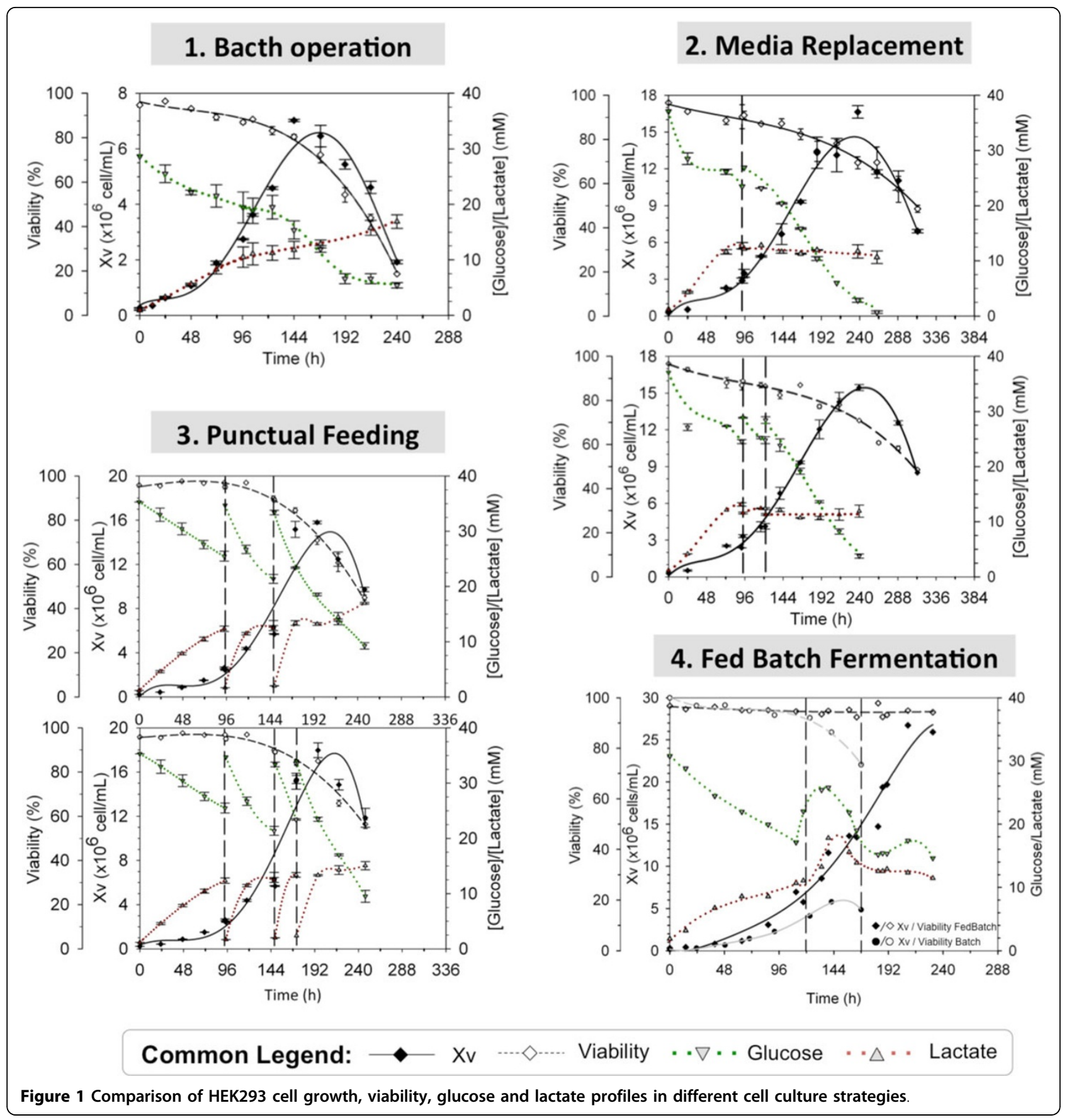

\section{Conclusions}

Punctual feeding and media replacement overcame the limit of $7 \cdot 10^{6} \mathrm{cell} / \mathrm{mL}$ encountered in batch mode operation indicating that nutrient depletion was one of the causes of that limit. Nevertheless, the elongation of $t_{\mu}$ found out performing MR suggests that the accumulation of by-products might not be ruled out.

The new limit on $\mathrm{Xv}_{\max }\left(\approx 17-18 \cdot 10^{6} \mathrm{cell} / \mathrm{mL}\right)$ encountered regardless the cell culture strategy, was outperformed by transferring $\mathrm{O}_{2}$ more efficiently in bioreactor system, reaching cell densities as high as $\mathrm{Xv}_{\max }=27 \cdot 10^{6}$ cell $/ \mathrm{mL}$. The monitoring and control of cell culture parameters (i.e. $\mathrm{pO}_{2}, \mathrm{pH}$ ) will enable to develop more accurate feeding strategies in order to achieve higher cell densities than those presented here (on going work).

Acknowledgements

We would like to thank Dr. Amine Kamen (BRI-NRC, Canada) for kindly providing the HEK 293 cell line. 


\section{References}

1. Nadeau I, Kamen A: Production of adenovirus vector for gene therapy. Biotechnology advances 2003, 20:475-489.

2. Geisse S, Fux C: Recombinant protein production by transient gene transfer into Mammalian cells. Methods in Enzymology 2009, 463:223-238.

3. Butler M: Animal cell cultures:recent achievements and perspectives in the production of biopharmaceuticals. Appl Microbiol Biotechnol 2005, 68:283-291.

4. Petiot E, Jacob D, Lanthier S, Lohr V, Ansorge S, Kamen A: Metabolic and Kinetic analyses of influenza production in perfusion HEK293 cell culture. BMC Biotechnol 2011, 11:84-96.

doi:10.1186/1753-6561-7-S6-P52

Cite this article as: Liste-Calleja et al:: Preliminary studies of cell culture strategies for bioprocess development based on HEK293 cells. BMC Proceedings 2013 7(Suppl 6):P52.

\section{Submit your next manuscript to BioMed Central} and take full advantage of:

- Convenient online submission

- Thorough peer review

- No space constraints or color figure charges

- Immediate publication on acceptance

- Inclusion in PubMed, CAS, Scopus and Google Scholar

- Research which is freely available for redistribution

Submit your manuscript at www.biomedcentral.com/submit
Ciomed Central 